\title{
Pulsed Electrochemical Deposited Nano-Iron for Water Treatment
}

\author{
Éva Fazakas', Mátyás-Karácsony Zsuzsanna1, Richárd Bak¹, Lajos K. Varga² \\ ${ }^{1}$ Bay Zoltán Nonprofit Ltd. for Applied Research, Budapest, Hungary \\ ${ }^{2}$ Wigner Research Center for Physics, Hungarian Academy of Sciences, Budapest, Hungary \\ Email: eva.fazakas@bayzoltan.hu
}

How to cite this paper: Fazakas, É., Zsuzsanna, M.-K., Bak, R. and Varga, L.K. (2017) Pulsed Electrochemical Deposited Nano-Iron for Water Treatment. American Journal of Analytical Chemistry, 8, 171-179. https://doi.org/10.4236/ajac.2017.83014

Received: November 7, 2016 Accepted: February 26, 2017 Published: March 1, 2017

Copyright (c) 2017 by authors and Scientific Research Publishing Inc. This work is licensed under the Creative Commons Attribution International License (CC BY 4.0).

http://creativecommons.org/licenses/by/4.0/

\section{Open Access}

\begin{abstract}
The application of nanotechnology in drinking water treatment and pollution cleanup is promising, as demonstrated by a number of field-based (pilot and full scale) and bench scale studies. In recent years, the use of zero-valent iron (ZVI) for the treatment of toxic contaminants in groundwater and wastewater has received wide attention and encouraging treatment efficiencies have been documented. In this review, nanoscale iron was prepared by pulse electrodeposition of nano iron by chemical reduction of iron chloride and iron sulfate. Our research focuses on iron nanoparticles preparation and its use for aqueous $\mathrm{Cr}(\mathrm{VI})$ reduction. The $\mathrm{Cr}(\mathrm{VI})$ reduction by the $\mathrm{nFe}^{0}$ prepared by electrochemical and blasting method at neutral $\mathrm{pH}$ were carried. The results show that blasting- $\mathrm{nFe}^{0}$ show lower reaction than the electrochemical-nFe ${ }^{0}$. It is because the blasting-nFe ${ }^{0}$ surface contains more $\mathrm{Fe}_{2} \mathrm{O}_{3}$ than the other one.
\end{abstract}

\section{Keywords}

Nano Iron, Electrodeposition, Blasting, Chromium(VI) Reduction

\section{Introduction}

Chromium is widely used in metallurgical, electroplating, production of paints and pigments, tanning, wood preservation [1] [2] [3], etc., thereby commonly identified in waters. Two primary oxidation states, $\mathrm{Cr}$ (VI) and $\mathrm{Cr}$ (III) species, are present in aqueous media. The former is highly toxic and carcinogenic to human and animals, while the latter is generally non-toxic [4] [5] [6]. Consequently, the reduction of the $\mathrm{Cr}(\mathrm{VI})$ to the $\mathrm{Cr}$ (III) is of environmental interest.

Nano iron powders have been used in permeable reactive barriers for aqueous $\mathrm{Cr}(\mathrm{VI})$ reduction in contaminated groundwater. Consequently, the reduction of the $\mathrm{Cr}(\mathrm{VI})$ to the $\mathrm{Cr}(\mathrm{III})$ is of environmental interest. Much work has been focused on the cleanup of $\mathrm{Cr}(\mathrm{VI})$-contaminated waters by various reducing rea- 
gents including hydrogen sulfide [7], divalent iron [8] [9], Fe(II)-bearing minerals [5] [10], thios and thiols [11] [12], etc. Recently, zero-valent iron $\left(\mathrm{Fe}^{0}\right)$ has been tested for the remediation of polluted waters, and it is established that halogenated hydrocarbons such as nitro- [13] [14], and chloro-compounds [15], toxic metals nitrate and arsenate [16] [17] [18] [19] [20] are effectively transformed by the $\mathrm{Fe}^{0}$ to relatively more benign products. Nanoscale iron (NSI) can also be a promising material for $\mathrm{Cr}(\mathrm{VI})$ removal from wastewater because of its large active surface area and high arsenic adsorption capacity. All described properties of Fe (iron) nanoparticles can be even used for decomposition of pollutants contained in the waste water, mainly for treatment of industrial sewage and hutch water. The usage of nanoiron can represent a significant qualitative step in the classical technologies of water treatment including drinking water. NSI can be also used for a reduction of the content of heavy metals, nitrates and phosphates in the drinking water. Nanotechnology has widespread application potential and offers also the possibility of an efficient removal of pollutants and germs in the area of wastewater treatment. The objectives of this study were to prepare NSI by pulse electrodeposition and to test its performance for efficient removal of pollutants from the wastewater. Electrochemical deposition is a cost effective, competitive method, which allows control over composition and microstructure of the powder.

\section{Materials and Methods}

\section{Synthesis of Nano-Iron Powder}

Iron nanoparticles were produced by pulse electrodeposition. In pulse electrodeposition, a D.C. current is applied for a short period time, ton, that is followed by a period of time when no current is applied, toff. Typical values for ton, and toff are between 5 and $200 \mathrm{~ms}$ and between 1 and $10 \mathrm{~ms}$ respectively. Through the use of a high current density as well as some grain growth inhibitors, such as saccharine, it is possible to increase the nucleation rate and reduce grain growth. The structure of the materials prepared was investigated using X-ray powder diffraction using Co Ka radiation and with a high resolution SEM from JEOLJSM$5600 \mathrm{LV}$

Sacharin $0.3 \mathrm{~g} \cdot \mathrm{dm}^{-3}$ and magnesium sulfate $\left(\mathrm{MgSO}_{4}\right)$ between 0 and $0.5 \mathrm{M}$ were added as grain refining agents, see Table 1 . The temperature of the solution was $25^{\circ} \mathrm{C}$ and the $\mathrm{pH}$ varied from 3.5 to 6.0 . Pulse current was between 10 and $20 \mathrm{~mA}$. All cases deposition were made on titanium cathode in order to facilitate their removal from the substrate which allows to perform experiments on self supported samples. One should also mention that the more additives are added to the solutions the larger is the contamination problem of the samples. For this reason, most of the experiments were done with the lowest amount of additive as possible.

\section{Results and Discussion}

Pulse current electrodeposition of nano-Fe was carried out to investigate the 
Table 1. Nano-Fe electrodeposition parameters and bath composition.

\begin{tabular}{ccccccc}
\hline Composition of bath & $\mathrm{Fe} 23$ & $\mathrm{Fe} 24$ & $\mathrm{Fe} 25$ & $\mathrm{Fe} 26$ & $\mathrm{Fe} 27$ & Fe28 \\
\hline $\mathrm{FeCl}_{3}$ & + & + & - & - & + & + \\
$\mathrm{FeSO}_{4}$ & + & + & - & - & + & + \\
$\left(\mathrm{NH}_{4}\right)_{2} \mathrm{Fe}\left(\mathrm{SO}_{4}\right)_{2}$ & - & + & - & - & + & + \\
$\mathrm{MgSO}_{4}$ & - & + & - & - & + & + \\
$\left(\mathrm{NH}_{4}\right)_{2} \mathrm{SO}_{4}$ & + & + & - & - & + & + \\
$\mathrm{saccharin}$ & + & + & - & - & + & + \\
$\mathrm{t}_{\text {on }}$ & 5 & 5 & 5 & 5 & 1 & 1 \\
$\mathrm{t}_{\text {off }}$ & 200 & 200 & 200 & 200 & 100 & 50 \\
$\mathrm{D}(\mathrm{nm})$ & 19.47 & 17.89 & 25.97 & 42.75 & 23.34 & 16.88 \\
$\eta(\%)$ & 61.7 & 41.7 & 16.7 & 21.5 & 29.2 & 10.5 \\
\hline
\end{tabular}

effect of $\mathrm{MgSO}_{4}$ on the microstructure and the reactivity of the electrodeposited films. Electrodeposition without $\mathrm{MgSO}_{4}$ electrolyte gave smaller grain size than with it.

XRD results in Figure 1, Figure 2. demonstrated that no other component were presented within the $\mathrm{Fe} 23$ and $\mathrm{Fe} 24$ samples. We used $\mathrm{MgSO}_{4}$ as a grain refining agent. The X-ray diffractorgram calculated the grain size of the NSI using Debye-Scherrer equation:

$$
\tau=\frac{K}{\beta \cdot \cos \theta} \cdot \lambda_{\mathrm{Co}}
$$

where, $\tau$ is the grain size; $K$ is a dimensionless shape factor, with a value $0.9, \lambda_{\mathrm{Co}}$ is the $\mathrm{X}$-ray wavelength $(1.788897 \AA) ; \beta$ is the line broadening at half and $\theta$ is the Bragg angle.

From the calculation, it turns out that the Fe23 grain size is about $19.47 \mathrm{~nm}$ and in the case of $\mathrm{Fe} 24$, it was $17.89 \mathrm{~nm}$.

The surface morphology of the nano-Fe was characterized with SEM (scanning electron microscope). The surface morphology changed as rough surface, where the concentration of $\mathrm{MgSO}_{4}$ increased. The reactivity of active surface of nano-Fe increasing as a function of decreasing of grain size in presence of $\mathrm{MgSO}_{4}$.

\subsection{Iron Oxid and Iron Ratio Measurements}

Iron oxid and iron ratio measurements are destined for the measurement of zero-valent iron nanoparticles content in a slurry. The method is based on the measurement of hydrogen volume, which is evolving during chemical reaction of zero-valent iron and an acid. This test is very simple and particularly fair minded: the volume of hydrogen is directly proportional to the amount of zero-valent iron; the amount of iron-oxides does not influence the volume of generated hydrogen, and it only slows down the reaction speed. 

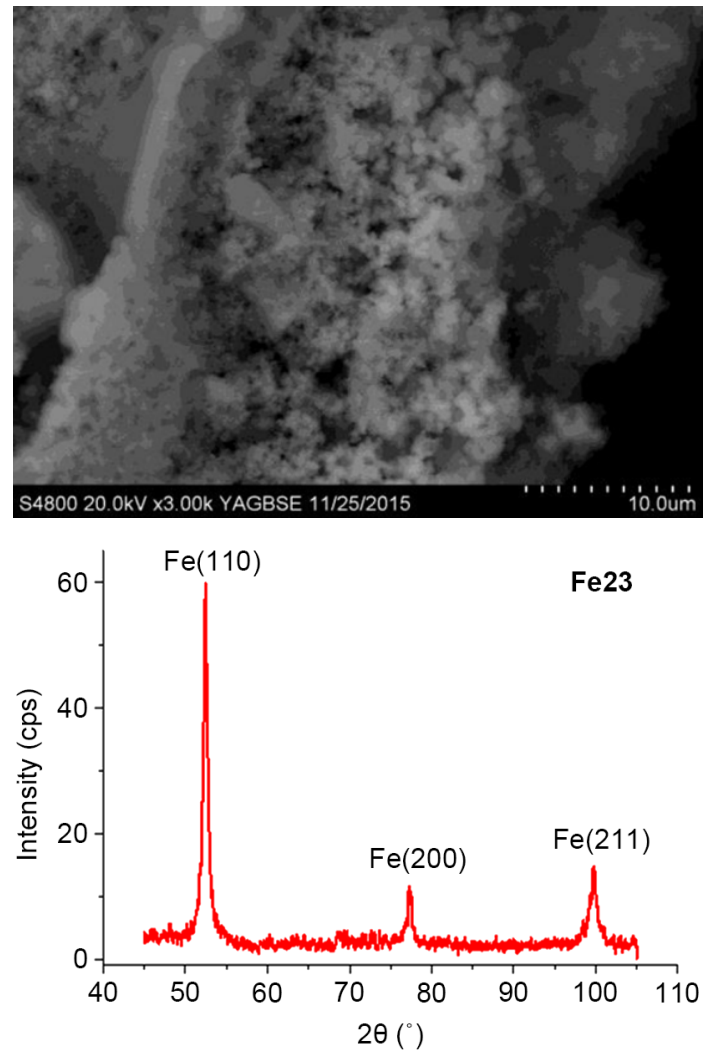

Figure 1. SEM and X-ray diffractogram of the Fe23 samples prepared without added $\mathrm{MgSO}_{4}$.
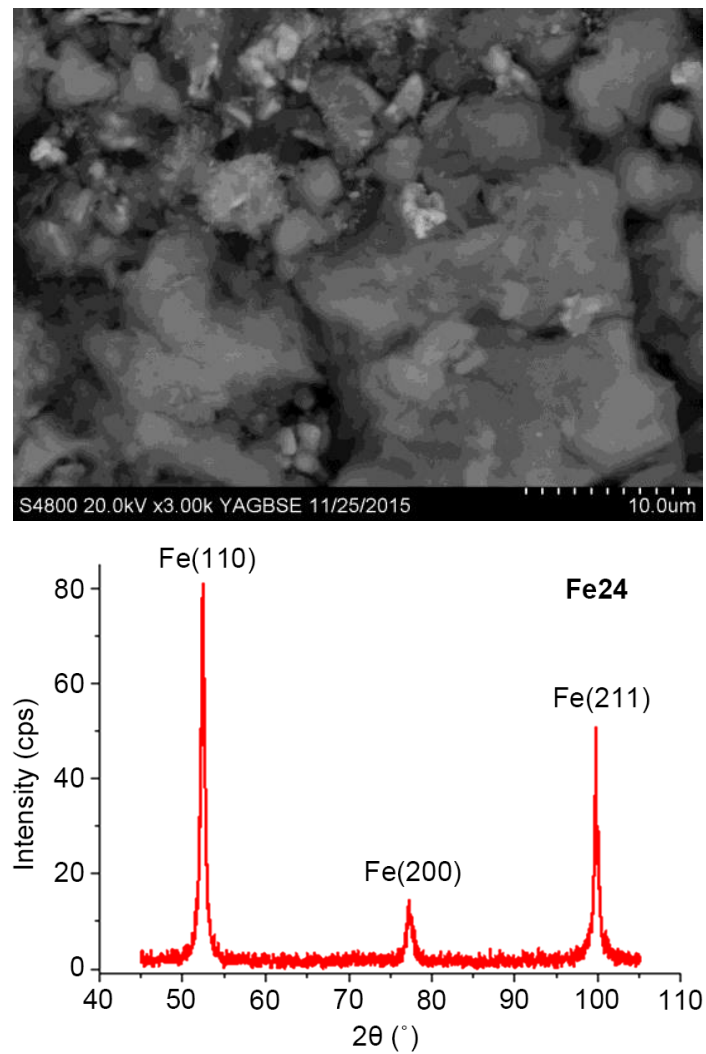

Figure 2. X-ray diffractogram of the Fe24 samples prepared with added $\mathrm{MgSO}_{4}$. 
Reaction of nZVI and the acid $\left(\mathrm{KHSO}_{4}\right)$ proceeds according to the following formula:

$$
\begin{gathered}
2 \mathrm{KHSO}_{4}+\mathrm{Fe} \rightarrow \mathrm{FeSO}_{4}+\mathrm{K}_{2} \mathrm{SO}_{4}+\mathrm{H}_{2} \\
55.85 \mathrm{~g} \mathrm{Fe} \rightarrow 22.41 \mathrm{dm}^{3} \mathrm{H}_{2}
\end{gathered}
$$

From previous formula it comes through, that $22.41 \mathrm{dm}^{3}$ of hydrogen is generated by reaction of $55.85 \mathrm{~g}$ of iron and sufficient amount of acid $\left(2 \mathrm{KHSO}_{4}\right)$. The weight and the concentration of nZVI is consequently calculated from the volume of evolved hydrogen.

For determination of the quality of nano-iron, we should measure the amount of iron-oxide in the deposited and in the further materials. First we used commercial zero-valent nanoiron powder for water treatment as reference material. Using the above methods we could measure the quantity of $\mathrm{H}_{2}$ gas from the chemical reaction where only the iron react with the potassium-bisulfate. On the curves of Figure 3. you can see some examples for the speed of $\mathrm{H}_{2}$ production. In average the total reaction time was about $12-14$ minutes at the reference and at our samples; except for the sample $\mathrm{nFe} 26$ and the sample from nFe-blasting. nFe-blasting samples was prepared by iron wires blasting method under water. For the samples preparation we used a low-value capacitor $(\mathrm{C} \sim 10-100 \mathrm{uF})$ and discharged a $100-500$ microns this iron wire. The discharge will be successful if the circuit behaves as a damped resonant circuit, with the condition:

$$
\frac{R^{2}}{4 L^{2}}<\frac{1}{L C}
$$

$\mathrm{nFe} 23, \mathrm{nFe} 24$ and $\mathrm{nFe} 26$ samples were prepared by electrochemical methods.

From Figure 3, it turns out that $\mathrm{nFe} 23, \mathrm{nFe} 24$ and $\mathrm{nFe} 26$ samples show the same results for the iron content as the commercial reference nZVI which has been used for water purification. Significant difference was not observed amount samples which were stored in different solution (see Table 2). In this case of sample stored under destillated water for the same time than the alcohol; the ratio of the iron was decreased but it is still acceptable. The reference iron-oxide samples didn't occur any reaction. Blasting $\mathrm{nFe}$ sample was not too reactive because the iron contains was about $7 \mathrm{wt} \%$, see Table 2 .

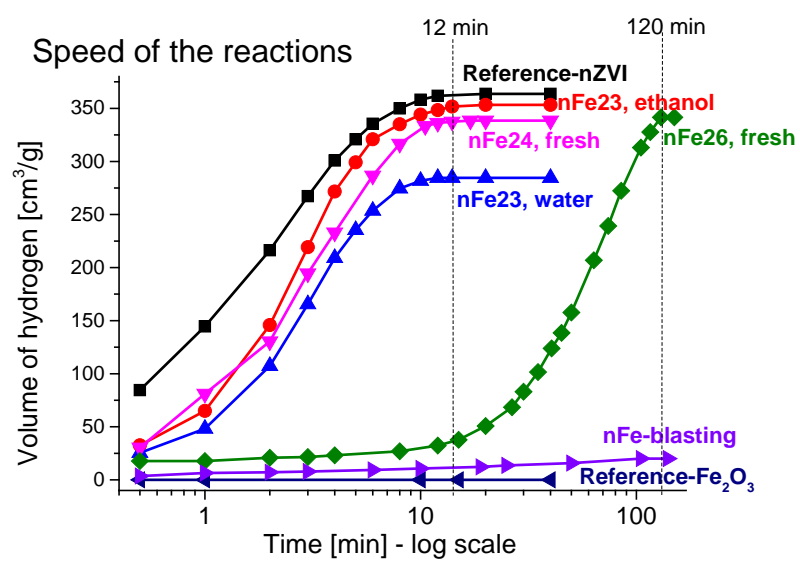

Figure 3. Iron oxide and iron ratio. 
Table 2. Summary of iron oxid and iron ratio measurements results.

\begin{tabular}{ccc}
\hline Sample & $\begin{array}{c}\text { Average nanoiron } \\
\text { content (wt\%) }\end{array}$ & $\begin{array}{c}\text { Average iron-oxide } \\
\text { content (wt\%) }\end{array}$ \\
\hline Reference commercial material & 87.7 & 12.3 \\
$\mathrm{nFe}$ 23-stored under ethanol for 3 weeks & 88.8 & 11.2 \\
$\mathrm{nFe}$ 23-stored under water for 3 weeks & 68 & 32 \\
$\mathrm{nFe}$ 24-freshly prepared & 87 & 13 \\
$\mathrm{nFe}$ 26-freshly prepared & 85 & 15 \\
Reference Iron-oxide powder & 0 & 94.5 \\
$\mathrm{nFe}$-prepared by blasting methods & 5.5 & \\
\hline
\end{tabular}

\section{2. $\mathrm{Cr}(\mathrm{VI})$ Reduction by the $\mathrm{nFe}$ at Neutral $\mathrm{pH}$}

The $\mathrm{Cr}(\mathrm{VI})$ concentration was quantified by the diphenyl carbazide method [21] on a UV-vis spectrophotometer (Jasco V-550 spectrophotometer).

Figure 4 show the $\mathrm{Cr}(\mathrm{VI})$ reduction by the $\mathrm{nFe}^{0}$ samples prepared with different methods.

The other underlined an indirect electron transfer that had the following reactions:

$$
\begin{gathered}
\mathrm{Fe}^{0}+\mathrm{CrO}_{4}^{2-}+4 \mathrm{H}_{2} \mathrm{O} \rightarrow \mathrm{Cr}(\mathrm{OH})_{3}+\mathrm{Fe}(\mathrm{OH})_{3}+2 \mathrm{OH}^{-} \\
\text {neutral } \mathrm{pH} \rightarrow \text { basic pH } \\
3 \mathrm{Fe}^{2+}+\mathrm{Cr}(\mathrm{VI}) \rightarrow \mathrm{Cr}^{3+}+3 \mathrm{Fe}^{3+}
\end{gathered}
$$

The $\mathrm{Cr}(\mathrm{VI})$ reduction by the $\mathrm{nFe} 0$ at neutral $\mathrm{pH}$ were carried out in batch mode in a home-made setup that used a borosilicate glass vessel with $100 \mathrm{~mL}$ effective volume as the reactor. To prevent the oxidation of $\mathrm{Fe}^{0}$ surface by air, $\mathrm{N}_{2}$ was supplied continuously into the setup during the experimental process. In each experiment, unless stated specially, $100 \mathrm{~mL} 10.0 \mathrm{mg} / \mathrm{L}$ potassium chromate was treated by $2.0 \pm 0.2 \mathrm{mg} \mathrm{Fe}{ }^{0}$ prepared by different methods. To investigate the effect of the co-existing organic matters on the $\mathrm{Cr}(\mathrm{VI})$ reduction, citric acid were added into the $\mathrm{Cr}(\mathrm{VI})$ solution.

Following the addition of the initial solution, $\mathrm{pH}$ was adjusted to 7.0 by adding $\mathrm{H}_{2} \mathrm{SO}_{4}$ and $\mathrm{NH}_{3} \cdot \mathrm{H}_{2} \mathrm{O}$, then $0.1 \mathrm{M}$ ammonium acetate solution was added to buffer the reaction $\mathrm{pH}$. Samples of $2.0 \mathrm{~mL}$ were taken at preset time intervals for an immediate analysis of $\mathrm{Cr}(\mathrm{VI})$ or $\mathrm{Fe}(\mathrm{II})$. Without the presence of co-existing organic matters in the reaction solution, precipitate emerged in the solution, and the samples were filtered to remove it before the measurement.

\subsection{Analytic Methods}

The Cr(VI) concentration was quantified by the diphenyl carbazide method [21] on an UV-spectrophotometer (Jasco V-550 spectrophotometer).

It should be noted that reactions underlined that $\mathrm{Fe}(\mathrm{II})$ was a main electron donator for the $\mathrm{Cr}(\mathrm{VI})$ reduction to occur in the solution homogeneously. This 


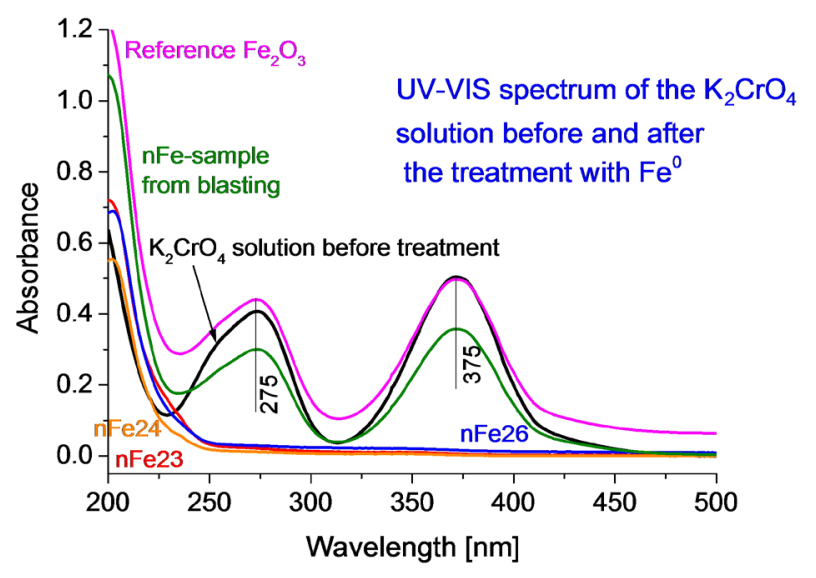

Figure 4. Spectrophotometer results of nFe prepared by different methods.

tuned mechanism for the $\mathrm{Cr}(\mathrm{VI})$ reduction by the $\mathrm{nFe}^{0}$ with the co-existing organic matters was supported by the following results. From the Figure 4, it turns out that the water reduction released $\mathrm{Fe}(\mathrm{II})$ in the solution, then the $\mathrm{Fe}(\mathrm{II})$ reduced $\mathrm{Cr}(\mathrm{VI})$ to $\mathrm{Cr}(\mathrm{III})$ homogeneously. In this study, the above mechanism of both the direct and indirect electron transfers appeared to work but tuned. It could be seen that during the reaction the $\mathrm{pH}$ increased from 7.0 to 7.7, which was in the neutral range. No precipitate was observed in the solution with a neutral $\mathrm{pH}$. Thus, we concluded that the iron species was present as the formation of $\mathrm{Fe}(\mathrm{II})$ prevented the precipitation of ferrous iron which otherwise occurred in the solution without any organic matter. The $\mathrm{Fe}(\mathrm{II})$ could also reduce the $\mathrm{Cr}(\mathrm{VI})$ homogenously as a main electron donor.

The best results show the samples of $\mathrm{nFe} 23, \mathrm{nFe} 24$ and $\mathrm{nFe} 26$, but in the case of blasting-nFe, the reaction was not complete.

\section{Conclusions}

There is an increasing interest in the use of NSI for the removal of contaminants from groundwater and wastewater. NSI has been successfully applied for the remediation/treatment of groundwater and wastewater contaminated with chlorinated organic compounds, nitroaromatic compounds, arsenic, heavy metals, nitrate, dyes, and phenol.

Nano iron powder was successfully prepared by electrochemical and blasting methods. The $\mathrm{Cr}(\mathrm{VI})$ reduction by the $\mathrm{nFe}^{0}$ prepared by electrochemical and blasting method at neutral $\mathrm{pH}$ were carried, the results show that blasting- $\mathrm{nFe}^{0}$ show lower reaction than the electrochemical- $\mathrm{nFe}^{0}$. It is because the blasting$n \mathrm{ne}^{0}$ surface contains more $\mathrm{Fe}_{2} \mathrm{O}_{3}$ than the other one.

\section{Acknowledgements}

This work was supported by TÉT_13_DST Indo-Hungarian (KTIA-DST) R\&D \&I Cooperation Programme with identification number of TÉT_13_DST-1-20130004 . 


\section{References}

[1] Ponder, S.M., Darab, J.C. and Mallouk, T.E. (2000) Remediation of Cr(VI) and $\mathrm{Pb}$ (II) Aqueous Solutions Using Supported, Nanoscale Zero-Valent Iron. Environmental Science \& Technology, 34, 2564-2569. https://doi.org/10.1021/es9911420

[2] Gheju, M. and Iovi, A. (2006) Kinetics of Hexavalent Chromium Reduction by Scrap Iron. Journal of Hazardous Materials, 135, 66-73.

https://doi.org/10.1016/j.jhazmat.2005.10.060

[3] Chen, S.-S., Cheng, C.-Y., Li, C.-W., Chai, P.-H. and Chang, Y.-M. (2007) Reduction of Chromatefrom Electroplating Wastewater from $\mathrm{pH} 1$ to 2 Using Fluidized Zero Valent Iron Process. Journal of Hazardous Materials, 142, 362-367. https://doi.org/10.1016/j.jhazmat.2006.08.029

[4] Melitas, N., Chuffe-Moscoso, O. and Farrell, J. (2001) Kinetics of Soluble Chromium Removalfrom Contaminated Water by Zerovalent Iron Media: Corrosion Inhibition and Passive Oxide Effects. Environmental Science \& Technology, 35, 39483953. https://doi.org/10.1021/es001923x

[5] He, Y.T. and Traina, S.J. (2005) Cr(VI) Reduction and Immobilization by Magnetite under Alkaline pH Conditions: The Role of Passivation. Environmental Science \& Technology, 39, 4499-4504. https://doi.org/10.1021/es0483692

[6] Zayed, A.M. and Terry, N. (2003) Chromium in the Environment: Factors Affecting Biological Remediation. Plant and Soil, 249, 139-156.

https://doi.org/10.1023/A:1022504826342

[7] Kim, C., Zhou, Q., Deng, B., Thornton, E.C. and Xu, H. (2001) Chromium(VI) Reduction Byhydrogen Sulfide in Aqueous Media: Stoichiometry and Kinetics. Environmental Science \& Technology, 35, 2219-2225. https://doi.org/10.1021/es0017007

[8] Eary, L.E. and Ral, D. (1988) Chromate Removal from Aqueous Wastes by Reduction with Ferrous Ion. Environmental Science \& Technology, 22, 972-977. https://doi.org/10.1021/es00173a018

[9] Du, G. and Espenson, J.H. (2006) Kinetics of the Reaction of Chromium(VI) with Tris(1,10-phenanthroline)Iron(II) Ions in Acidic Solutions. Anion and Medium Effects: Perchlorate versus Triflate. Inorganic Chemistry, 45, 1053-1058. https://doi.org/10.1021/ic0511524

[10] Ronald, R. and Patterson, F. (1997) Scott, Reduction of Hexavalent Chromium by Amorphous Iron Sulfide. Environmental Science \& Technology, 31, 2039-2044. https://doi.org/10.1021/es960836v

[11] Szulczewski, M.D., Helmke, P.A. and Bleam, W.F. (2001) XANES Spectroscopy Studies of $\mathrm{Cr}$ (VI) Reduction by Thiols in Organosulfur Compounds and Humic Substances. Environmental Science \& Technology, 35, 1134-1141. https://doi.org/10.1021/es001301b

[12] Perez-Benito, J.F., Saiz, N. and Amat, E. (1998) Catalysis by Zinc Ion in the Reactions of Carcinogenic Chromium(VI) with Thiols. Journal of Molecular Catalysis A: Chemical, 135, 1-10. https://doi.org/10.1016/S1381-1169(97)00284-7

[13] Hung, H.M., Ling, F.H. and Hoffmann, M.R. (2000) Kinetics and Mechanism of the Enhanced Reductive Degradation of Nitrobenzene by Elemental Iron in the Presence of Ultrasound. Environmental Science \& Technology, 34, 1758-1763. https://doi.org/10.1021/es990385p

[14] Wang, C.B. and Zhang, W. (1997) Synthesizing Nanoscale Iron Particles for Rapid and Complete Dechlorination of TCE and PCBs. Environmental Science \& Technology, 31, 2154-2156. https://doi.org/10.1021/es970039c

[15] Oh, B.T., Just, C.L. and Alvarez, P.J.J. (2001) Hexahydro-1,3,5-Trinitro-1,3,5-Tri- 
azine Mineralizationby Zerovalent Iron and Mixed Anaerobic Cultures. Environmental Science \& Technology, 35, 4341-4346. https://doi.org/10.1021/es010852e

[16] Kim, J. and Benjamin, M.M. (2004) Modeling a Novel Ion Exchange Process for Arsenic and Nitrate Removal. Water Research, 38, 2053-2062.

https://doi.org/10.1016/j.watres.2004.01.012

[17] Zouboulis, A. and Katsoyiannis, I. (2002) Removal of Arsenates from Contaminated Water by Coagulation-Direct Filtration. Separation Science and Technology, 37, 2859-2873. https://doi.org/10.1081/SS-120005470

[18] Ning, R.Y. (2002) Arsenic Removal by Reverse Osmosis. Desalination, 143, 237-241. https://doi.org/10.1016/S0011-9164(02)00262-X

[19] Gihring, T.M., Druschel, G.K., Mccleskey, R.B., Hamers, R.J. and Banfield, J.F. (2001) Rapid Arsenite Oxidation by Thermus aquaticus and Thermus thermophilus. Field and Laboratory Investigations. Environmental Science \& Technology, 35, 3857-3862. https://doi.org/10.1021/es010816f

[20] Zhang, Q.L., Lin, Y.C., Chen, X. and Gao, N.Y. (2007) A Method for Preparing Ferric Activated Carbon Composites Adsorbents to Remove Arsenic from Drinking Water. Journal of Hazardous Materials, 148, 671-678. https://doi.org/10.1016/j.jhazmat.2007.03.026

[21] Lee, T., Lim, H., Lee, Y. and Park, J. (2003) Use of Waste Iron Metal for Removal of Cr(VI) from Water. Chemosphere, 53, 479-485. https://doi.org/10.1016/S0045-6535(03)00548-4

\section{Scientific Research Publishing}

Submit or recommend next manuscript to SCIRP and we will provide best service for you:

Accepting pre-submission inquiries through Email, Facebook, LinkedIn, Twitter, etc. A wide selection of journals (inclusive of 9 subjects, more than 200 journals)

Providing 24-hour high-quality service

User-friendly online submission system

Fair and swift peer-review system

Efficient typesetting and proofreading procedure

Display of the result of downloads and visits, as well as the number of cited articles

Maximum dissemination of your research work

Submit your manuscript at: http://papersubmission.scirp.org/

Or contact ajac@scirp.org 